\title{
Claw Hardness of Dairy Cows: Relationship to Water Content and Claw Lesions
}

\author{
T. F. Borderas, ${ }^{1,2}$ B. Pawluczuk, ${ }^{1}$ A. M. de Passillé, ${ }^{1}$ and J. Rushen ${ }^{1}$ \\ ${ }^{1}$ Dairy and Swine Research and Development Centre, Agriculture and Agri-Food Canada, \\ Lennoxville, QC, Canada J1M 1 Z3 \\ 2Universidad Autónoma Metropolitana-Xochimilco, Depto. de Producción Agrícola y Animal, \\ 04320 Coyoacán D.F., Mexico
}

\begin{abstract}
Lameness of dairy cows is a major welfare and economic problem. Degree of hardness of claws may influence chances for injury or for claw lesions, and exposure of claws to moisture may make them soft. To assess the relationship among hardness of the claw horn, quantity and rate of absorption of water, and incidence of claw lesions, 4 experiments were carried out. In the first 3 experiments, we soaked pieces of the claw horn in water for 12 to $24 \mathrm{~h}$. Soaked claws gained weight and became significantly softer, indicating that water was absorbed. One-third of the total water absorbed in $24 \mathrm{~h}$ occurred during the first hour. Base of the abaxial and dorsal walls of the claw was harder than the sole, but became softer more rapidly when soaked in water. In the 4 th experiment, significant negative correlations were detected between claw hardness of cows and severity of claw lesions, suggesting that cows with softer claws have the most severe claw lesions. Claw horn tissue absorbs water rapidly and claw hardness decreases with moisture content, suggesting that brief exposures to moist surfaces result in claws that absorb water and consequently become softer. The relationship between hardness and claw lesions indicates that cows with softer claws are at greater risk for lameness.
\end{abstract}

(Key words: lameness, claw lesion, claw hardness, claw water content)

Abbreviation key: $\mathbf{E R}=$ heel erosion, $\mathbf{S H}=$ sole hemorrhage, $\mathbf{U L}=$ sole ulcer, $\mathbf{W H}=$ white line hemorrhage .

\section{INTRODUCTION}

Lameness is one of the most important causes of financial loss and distress in dairy cattle (Whitaker et al., 1983; Esslemont and Kossaibati, 1997), and lesions in the claw are the most common visible pathology asso-

Received October 28, 2003.

Accepted February 9, 2004.

Corresponding author: T.F. Borderas; e-mail: borderasf@agr.gc.ca. ciated with lameness (Vermunt and Greenough, 1995). Quality of the cow's claws, especially their hardness, may influence the likelihood that the cow will suffer from claw lesions. Although various factors (i.e., nutrition, genetics, etc.) affect claw quality, the environment in which the cow is housed is very important. Environmental effects on claw quality include those caused by season, type of walking surface, and wetness of the claw (Huang et al., 1995). Resistance of horn of the claw to environmental effects likely depends on its hardness because hardness influences rate of horn wear and erosion (Vermunt and Greenough, 1995).

Prolonged exposure of the claw to water likely reduces hardness of the horn of the claw. Several reports (Martig et al., 1980; Dietz and Prietz, 1981; Higuchi et al., 2003) have shown that water content of the horn of the claw is related negatively to its hardness. Cows kept on slatted floors, which reduce exposure of the claw to water, tend to have harder claws (Georg and Meyer, 2002). Some researchers (Maclean, 1971; Wells et al., 1995) claim that this relationship puts cows with wet claws at a higher risk of developing claw problems because the horn resistance is diminished. In support of this assumption, Higuchi and Nagahata (2001) found greater water content in claws of cows with claw problems compared with healthy cows. Surveys (Eddy and Scott, 1980; Williams et al., 1986) have identified an association between rainfall and the incidence of claw lesions in cows.

However, these studies are correlational, and so the causal mechanisms are not clear. For example, softer claws may absorb more water. Correlations between rainfall and claw lesions may be due to seasonal changes in proliferation and keratinisation of claw cells (MacCallum et al., 2002). Thus, it is not clear whether these changes in hardness and water content are the cause or consequence of claw diseases. Furthermore, some studies (Leopold and Prietz, 1980) did not find a correlation between horn abrasion and horn water uptake, whereas others (Martig et al., 1980; Arkins et al., 1986) could not establish a relationship between the water content of the claw and the incidence of claw diseases. 
Previous research has relied mainly on correlating measures of horn hardness with water content of thin layers of the horn removed from claw surfaces. However, little information is available about the rate of uptake of water by claw horn tissue or of resulting variations in hardness of different parts of horn structure.

In a series of experiments, our objective was to estimate the rate of water uptake by the horn of the claw and apply an experimental approach to evaluate how changes in water content affected hardness of different regions of the horn. We also examined the correlation between claw hardness and the incidence and severity of various claw lesions.

\section{MATERIALS AND METHODS}

\section{Experiment 1}

The aim of this experiment was to estimate the quantity of water absorbed, the rate of absorption by the claw horn, and the relationship to changes in hardness of horn tissue. The front left claw of 4 cows from various breeds was collected from a nearby slaughterhouse. The inner and outer digits were separated, and 3 segments of $2.5 \times 2.5 \mathrm{~cm}$ were cut from the wall surface of each digit. The 3 segments from one digit were then soaked in water, whereas the 3 segments from the other digit were left dry. Across cows, an equal number of inner and outer digits were either soaked or left dry. Soaked segments were left in tap water for $12 \mathrm{~h}$ at $4^{\circ} \mathrm{C}$. At 0 and $12 \mathrm{~h}$ of the soaking period, each segment was weighed (to estimate water content), and 3 measures of hardness were made from the surface of each piece using a durometer (Type D model 1600; Rex Gauge Company Inc., Buffalo Grove, IL) as reported by Distl et al. (1984). Reading of durometer measurements was done by pressing the instrument by hand against a piece of claw until the flat tip of the instrument touched the surface.

All pieces were then oven-dried at $102^{\circ} \mathrm{C}$ before weight and hardness measurements were made at 24 and $36 \mathrm{~h}$. Because the right side of the claw was damaged for one cow, pieces from that cow were soaked only.

\section{Experiments 2 and 3}

In the previous experiment, water may have been absorbed from the cut surface of the claw segments. To prevent such absorption, we evaluated the rate of water absorption and loss in the whole, uncut digit and its relation to changes in hardness of different anatomical points of this structure. These experiments used the same methodology, with the difference that Experiment
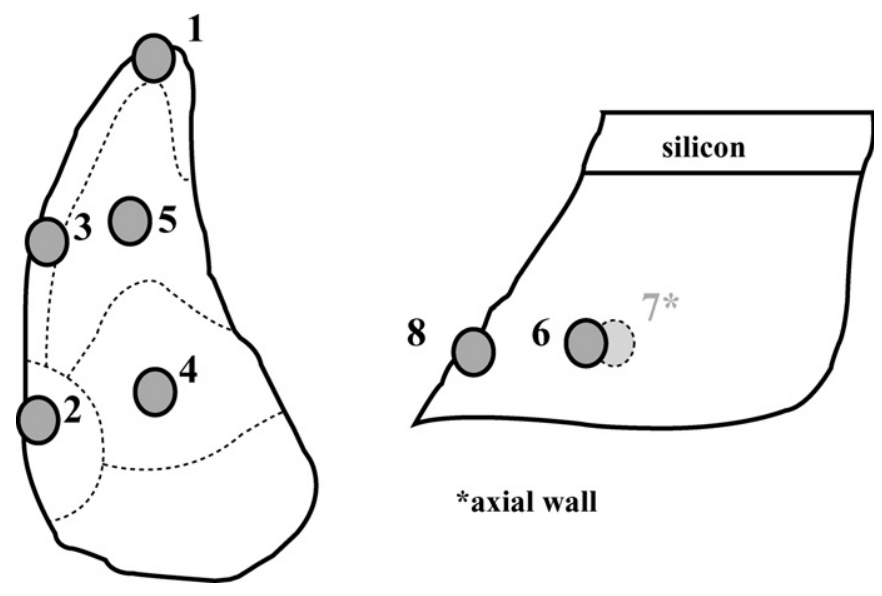

*axial wall
Figure 1. Hardness measuring points and silicon area. Point 1. The tip of the toe at sole midway between white line and claw edge. Point 2. Abaxial wall-sole junction midway between white line and claw edge. Point 3. Midpoint between Points 1 and 2. Point 4. Midpoint at the sole-bulb junction. Point 5. Midpoint at the apex of the sole. Point 6 . Abaxial wall at $2 \mathrm{~cm}$ from the sole, midway between the tip of the toe and the sole-bulb juction. Point 7 . Axial wall at $2 \mathrm{~cm}$ from the sole, midway between the tip of the toe and the sole-bulb junction. Point 8. Dorsal wall at $2 \mathrm{~cm}$ from the sole.

2 was carried out at a room temperature of $5^{\circ} \mathrm{C}$ and Experiment 3 at $20^{\circ} \mathrm{C}$.

Claws. For each experiment, 4 claws (total of 8 claws) were collected from a nearby slaughterhouse from cows of different breeds (Holstein-Friesian, Charolais, Limousin, and Brown Swiss). Claws were collected $24 \mathrm{~h}$ before the experiment began. Each claw was cut at the coronet and separated into its digits. Exposed tissue at the top of the claw was then covered with silicon sealant from the top down to $2 \mathrm{~cm}$ below the coronet. The sealant was applied to prevent water absorption and evaporation from the exposed area.

Treatments. One of the 2 digits from each claw was assigned to a soaking treatment in distilled water, balancing between left and right claws and inner and outer digits. The remaining digit was not soaked, but was exposed to air in either a cold room $\left(5^{\circ} \mathrm{C}\right.$; Experiment $2)$ or a warm room $\left(20^{\circ} \mathrm{C}\right.$; Experiment 3$)$. Soaked digits were immersed in a 2-L plastic container filled with $600 \mathrm{~mL}$ of water and covered. Unsoaked digits were placed next to a 2-L plastic covered container filled with $600 \mathrm{~mL}$ of water (to control for humidity).

Recording of hardness. Claw hardness was measured as described in Experiment 1. The durometer was used twice on all digits (soaked and unsoaked) from the 8 points shown in Figure 1. Measurements were made at $0,4,8,12$, and $24 \mathrm{~h}$ after soaking began. These points were taken as representatives of the base of the claw wall (Points 1, 2, and 3), the sole of the claw (Points 4 and 5), or the horn wall (Points 6, 7, and 8). According 
to the recommendations established at the Sixth Symposium on Diseases of the Ruminant Digit in Liverpool, held in 1990 (Greenough and Weaver, 1997), Points 1 and 3 are, respectively, located in Zones 1 and 2 (white zone at the toe and abaxial white zone). Point 2 is located in Zone 3 (abaxial wall-sole junction). However, no measurements were made on the white line itself for these 3 points, but in the base of the wall (stratum medium), between the white line and the edge of the claw. Point 4 is located in Zone 4, the sole-bulb junction, a region of the sole in which the majority of sole ulcers (UL) develop (Blowey et al., 2000). Point 5 is located in Zone 5 (apex of the sole). Because some claws had irregular surfaces, which complicated the measurement of hardness, a very light abrasion was made at the measuring points with a sandstone-tipped drill. Even with this procedure, the readings from Point 7 were inconsistent because of the grooved and curved surface of the inner wall. Because it was not possible to obtain valid measures from this point, these measures were discarded.

Weighing and Drying Procedure. Each digit and its container were weighed together and separately every hour until $4 \mathrm{~h}$ and thereafter at $6,8,10,12$, and $24 \mathrm{~h}$. To remove excess surface water, soaked and unsoaked digits were placed over a paper towel and wrapped for a few seconds before measuring. Water in the containers was replaced after each measurement to minimize changes in distilled water properties.

After $24 \mathrm{~h}$, all digits were left exposed to the air at room environment and allowed to dry out. Weight and hardness measurements were made according to the same schedule as during the soaking procedure until $48 \mathrm{~h}$.

\section{Experiment 4}

The aim of this experiment was to determine the correlation between occurrence of claw lesions and hardness of the claw.

Thirty-nine Holstein dairy cows with a mean $( \pm \mathrm{SE})$ parity of $1.7 \pm 0.2$ and $168 \pm 13$ DIM were housed in individual tie stalls with Pasture Mat on the stall floors and professionally claw-trimmed twice $30 \mathrm{~d}$ apart. During claw trimming, hardness of the rear claws was measured, and occurrence of various claw lesions was recorded. Hardness measurements were made before trimming using the durometer, as described in Experiment 1 . To reduce the time taken during the claw trimming procedure, we concentrated on the sole of the claw, because this is where lesions occur most often. We measured hardness at Points 4 and 5 and at new point (1b), at the tip of the toe near Point 1, but on the sole (Figure 1). Hardness of the wall at Point 6 also was measured.
During and after trimming, visible claw lesions were recorded as sole hemorrhages (SH), white line hemorrhages (WH), heel erosion (ER), UL, and digital dermatitis. Severity of lesions was recorded after trimming using a 1 - to 3 -point ordinal scale $(1=$ mild to $3=$ severe; Arkins et al., 1986). Digital photos were made of each claw to confirm lesions.

\section{Statistical Analyses}

Experiment 1. Mean hardness was calculated from the 3 measures taken at each time. Results were analyzed by mixed model analysis, as recommended by Littell et al. (1998) for repeated measures (SAS Inst., Inc., Cary, NC). The mixed model included cow, treatment (soaked vs. unsoaked), and time as factors. Variables included weight and hardness. Each claw segment was the experimental unit. Results were analyzed separately for the soaking period from 0 to $12 \mathrm{~h}$, and the drying period from 12 to $36 \mathrm{~h}$. Pearson correlations were carried out between all measures at each sampling time.

Experiments 2 and 3. Data from each experiment were analyzed separately. Analyses also were done separately for the soaking period, from 0 to $24 \mathrm{~h}$, and the drying period, from 24 to $48 \mathrm{~h}$. As recommended by Littell et al. (1998) for repeated measures, a mixed model analysis was used. The model included digit, time, and treatment (soaked vs. unsoaked) as factors. Variables included the change in weight by claws, hardness of each of the 8 points previously described, average hardness based on all 8 points, average hardness of points on the base of the wall (Points 1, 2, and 3), average hardness of the points on the claw wall (Points 6 and 8), and average hardness of the points on the sole (Points 4 and 5). Because amount of water absorbed is reflected in the difference in weight between samples at $0 \mathrm{~h}$ and the weight at the other sampling times, the percentage change in weight was calculated as follows: (weight of digit - initial weight at $0 \mathrm{~h} /$ initial weight at $0 \mathrm{~h}) \times 100$.

Experiment 4. Severity scores of each type of lesion (SH, WH, ER, UL, and digital dermatitis) were added together to produce a summed severity score for each type of lesion for each cow. In addition, the summed severity scores were added together across lesion types to produce an overall lesion severity score for each cow. Associations between these claw lesion scores and measures of claw hardness at the different points (hardness at each individual point, average hardness for sole measures and average hardness for whole claw) were examined using Spearman's rank correlations. A paired $t$ test was used to test the difference in hardness between the 2 trimming dates. Fisher's exact test was performed 
Table 1. Least square mean values for weight ( $\mathrm{g}$ ) and hardness (D units) of soaked or unsoaked claw pieces at 0 and $12 \mathrm{~h}$ (soaking period).

\begin{tabular}{|c|c|c|c|c|}
\hline \multirow[b]{2}{*}{ Time } & \multicolumn{2}{|c|}{ Weight } & \multicolumn{2}{|c|}{ Hardness } \\
\hline & Soaked digits & Unsoaked digits & Soaked digits & Unsoaked digits \\
\hline $\begin{array}{l}0 \mathrm{~h} \\
12 \mathrm{~h}\end{array}$ & $\begin{array}{l}17.3 \pm 1.1 \\
17.7 \pm 1.1\end{array}$ & $\begin{array}{l}16.4 \pm 1.1 \\
16.4 \pm 1.1\end{array}$ & $\begin{array}{l}69.8 \pm 1.7 \\
65.3 \pm 1.7\end{array}$ & $\begin{array}{l}69.4 \pm 2.3 \\
69.5 \pm 2.3\end{array}$ \\
\hline
\end{tabular}

to test the differences in claw lesion scores between the 2 trimming dates.

\section{RESULTS}

\section{Experiment 1}

Soaking period from 0 to $12 \boldsymbol{h}$. Table 1 shows the least square mean values for weight and hardness for 0 and $12 \mathrm{~h}$ in each treatment. A treatment $\times$ time interaction $(P<0.001)$ was detected on weight and hardness. Soaked digits showed an increase in weight and a decrease in hardness during the soaking period. Unsoaked digits showed no change in weight or hardness. Significant correlations at $12 \mathrm{~h}$ were detected between hardness and change in weight $(\mathrm{r}=-0.52 ; \mathrm{n}=21 ; P=0.015)$.

Drying period from 12 to $36 \boldsymbol{h}$. An effect of cow $(P$ $<0.01)$ and time $(P<0.001)$, but no effect of treatment $(P=0.43)$, cow $\times$ treatment $(P=0.23)$ or time $\times$ treatment $(P=0.28)$ on weight measurements was detected from 12 to $36 \mathrm{~h}$. In the case of hardness, only a significant effect of time $(P<0.001)$ was found. However, an interaction between time and treatment tended $(P=$ $0.06)$ to occur.

Weight and hardness variables were then recalculated to express as a percentage change from the 12-h baseline. These new measurements were analyzed with the same mixed model, and interactions of time $\times$ treatment $(P=0.023$ for weight changes and $P=0.047$ for hardness changes) were found (Table 2). As expected, the soaked digits lost weight because of water evaporation and consequently increased in hardness.

\section{Experiment 2}

Soaking period from 0 to $24 \mathrm{~h}$. There was an effect of treatment $(P=0.0003)$, time $(P<0.001)$ and their interaction $(P<0.001)$ on the weight of the digit (Table $3)$. Figure 2 shows mean weight change of digits for each treatment.

As expected, digits under the soaking treatment absorbed up to $1.35 \mathrm{~g}$ of water per $100 \mathrm{~g}$ of tissue, whereas the unsoaked digits lost approximately $0.35 \mathrm{~g}$ of water per $100 \mathrm{~g}$ of tissue. Weight gain was most rapid during the first hour, with almost one-third of the total gain occurring in that period of time.

In the case of hardness, there was no effect of treatment, but there were effects of time $(P=0.003)$ and treatment ( time interaction $(P<0.001)$. Figure 3 shows the mean values of hardness for digits for each treatment.

It can be seen that soaked digits softened, whereas unsoaked digits showed some hardening or remained as hard as in the beginning.

When hardness points were grouped according to the regions of the claw described previously, interactions of treatment $\times$ time were detected $(P<0.001$ for the average of Points 1, 2, and 3; $P=0.049$ for the average of Points 6 and 8; and $P=0.039$ for the average of Points 4 and 5). Mean values for average hardness (expressed as percentage change) of the soaked digits in each group are presented in Figure 4.

The points of the base of the wall (Points 1, 2, and 3) showed the largest and earliest changes in hardness. The most rapid softening of this region occurred during the first $4 \mathrm{~h}$. The sole region (Points 4 and 5) seemed to soften steadily during the observation period. The wall region (Points 6 and 8) showed the least dramatic changes.

Drying period from 24 to $48 \mathrm{~h}$. During the drying period, effects on weight changes were detected for treatment $(P=0.047)$, time $(P<0.001)$, and their inter-

Table 2. Least square mean values for the percentage change in weight and hardness during the drying period by treatment.

\begin{tabular}{lccccc}
\hline \multirow{2}{*}{$\begin{array}{l}\text { Time into the } \\
\text { drying period }\end{array}$} & \multicolumn{2}{c}{ Weight } & & \multicolumn{2}{c}{ Hardness } \\
\cline { 2 - 3 } \cline { 5 - 6 } & Soaked digits & Unsoaked digits & & Soaked digits & Unsoaked digits \\
\hline $0 \mathrm{~h}$ & 0 & $-1.1 \pm 0.8$ & & 0 & $1.2 \pm 3.1$ \\
$12 \mathrm{~h}$ & $-19.5 \pm 0.7$ & $-17.5 \pm 0.8$ & & $28.2 \pm 2.4$ & $20.3 \pm 3.1$ \\
$24 \mathrm{~h}$ & $-22.5 \pm 0.7$ & $-20.7 \pm 0.7$ & & $31.7 \pm 2.4$ & $23.7 \pm 3.1$ \\
\hline
\end{tabular}


Table 3. Mean $( \pm \mathrm{SD})$ hardness at each point tested in Experiment 2 at $0 \mathrm{~h}$.

\begin{tabular}{ll}
\hline Variable & Mean \pm SD \\
\hline Point 1 & $70.4 \pm 9.3$ \\
Point 2 & $61.6 \pm 18.8$ \\
Point 3 & $64.7 \pm 10.1$ \\
Point 4 & $43.0 \pm 16.8$ \\
Point 5 & $48.7 \pm 13.2$ \\
Point 6 & $77.3 \pm 4.6$ \\
Point 7 & $74.6 \pm 3.7$ \\
Point 8 & $78.4 \pm 4.3$ \\
Mean $~$ & $64.9 \pm 7.9$ \\
Mean 1, 2, 3 (base of the wall) & $65.6 \pm 10.7$ \\
Mean 4, 5 (sole) & $45.9 \pm 14.2$ \\
Mean 6, 8 (dorsal and abaxial wall) & $77.9 \pm 3.5$ \\
\hline
\end{tabular}

action $(P<0.001)$. Figure 5 shows mean values of weight changes from 24 to $48 \mathrm{~h}$ by treatment at $5^{\circ} \mathrm{C}$.

Digits in soaking treatment lost around $1 \mathrm{~g}$ of water per $100 \mathrm{~g}$ of tissue during the drying period, whereas unsoaked digits lost just $0.4 \mathrm{~g}$ of water per $100 \mathrm{~g}$ of tissue.

Because considerable differences in hardness were detected between treatments after $24 \mathrm{~h}$, no differences were subsequently found for treatment, time, or their interaction during the drying period. In contrast, when hardness values were calculated as a percentage change in hardness, significant differences were detected in average hardness at $5^{\circ} \mathrm{C}$ because of treatment $(P=0.002)$, time $(P<0.001)$, and their interaction $(P=0.001)$.

Total gain in hardness in D units was 14.26 for soaked digits and 5.76 $\mathrm{D}$ units for unsoaked digits during the drying period (24 to $48 \mathrm{~h}$; Figure 6 ). When hardness points were grouped according to the regions of the claw, time $\times$ treatment interactions $(P<0.05)$ were detected for average hardness of Points 1, 2, and 3.

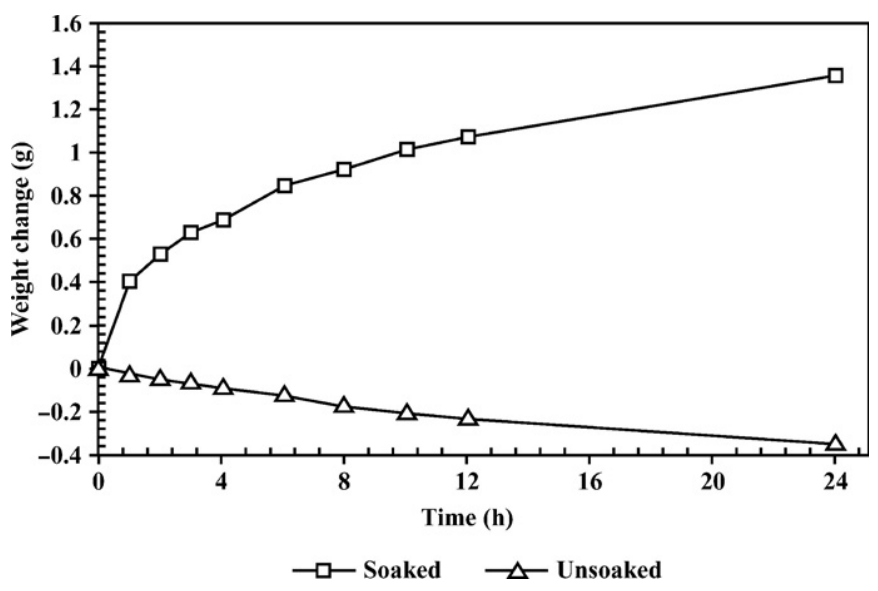

Figure 2. Least square mean values of change of weight (g) for soaked and unsoaked digits in distilled water at $5^{\circ} \mathrm{C}(\mathrm{SE}=0.09)$.

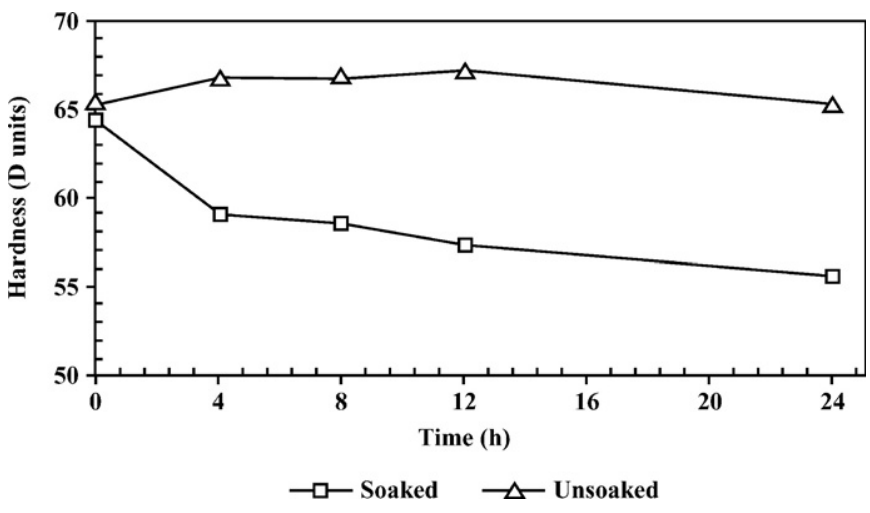

Figure 3. Least square mean values of hardness (Durometer scores) for soaked and unsoaked digits in distilled water at $5^{\circ} \mathrm{C}$ $(\mathrm{SE}=3.73)$.

\section{Experiment 3}

Soaking period from 0 to $24 \boldsymbol{h}$. As in Experiment 2 , there was an effect of treatment, time, and treatment $\times$ time interaction $(P<0.0001)$ on weight change. Water uptake was $1.6 \mathrm{~g}$ of water $/ 100 \mathrm{~g}$ of tissue in soaked digits. Unsoaked digits had a loss of water of $1.10 \mathrm{~g} /$ $100 \mathrm{~g}$ of tissue.

For hardness average, an effect $(P<0.001)$ of treatment, time, and their interaction was detected. Soaked digits experienced a softening of almost $13 \mathrm{D}$ units (71 to $58 \mathrm{D}$ units) in $24 \mathrm{~h}$. Unsoaked digits hardened around $5 \mathrm{D}$ units. When hardness points were grouped according to the regions of the claw, effects $(P<0.001)$ of treatment, time, and their interaction were detected for all 3 groups.

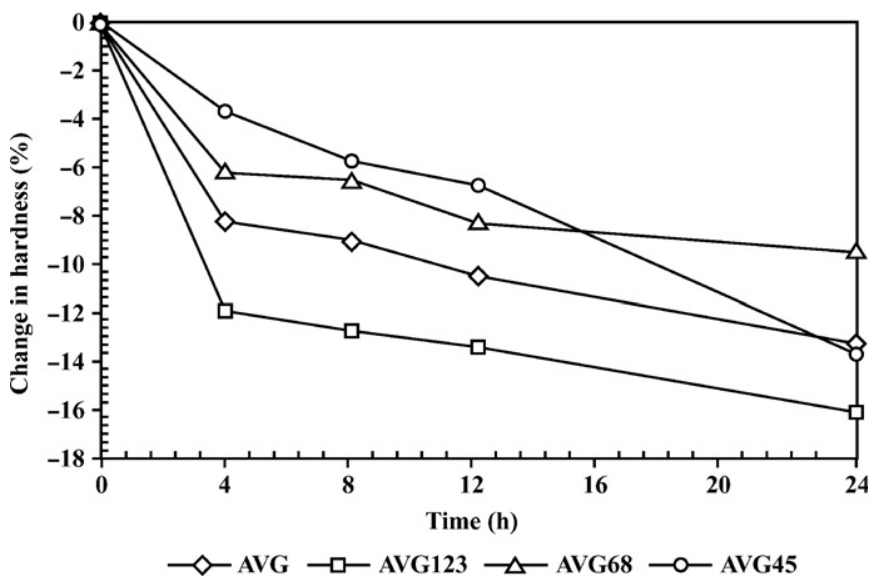

Figure 4. Least square mean values for percentage of change in hardness by hoof region over time of soaking. AVG = mean hardness of all points combined, AVG123 = mean hardness for points on the weight-bearing surface, AVG68 = mean hardness for points on the outer wall, AVG45 = mean hardness for points on the sole. 


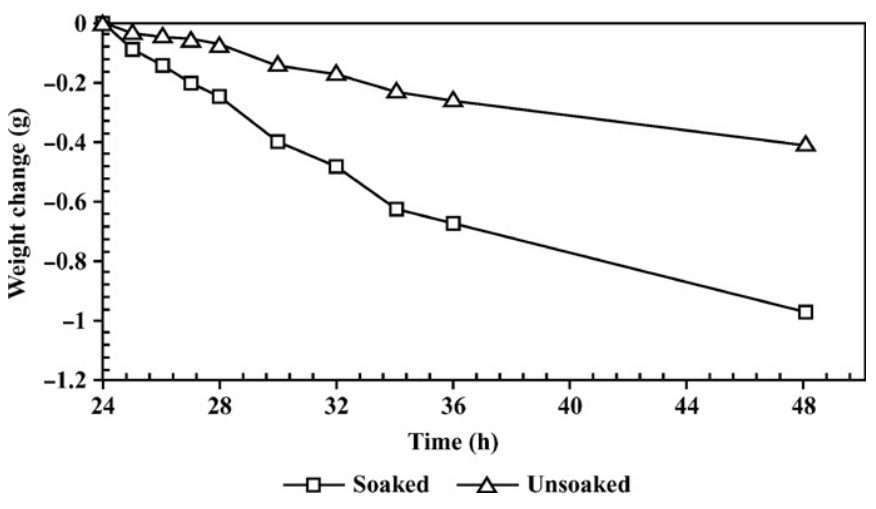

Figure 5. Least square mean values for weight change (g) by treatment from 24 to $48 \mathrm{~h}$ at $5^{\circ} \mathrm{C}$ during the drying period.

\section{Experiment 4}

Points on the sole (Points $1 \mathrm{~b}, 4$, and 5) were softer $(P<0.001)$ than Point 6 on the claw wall (Figure 7$)$. When comparing May vs. June measurements (first vs. second trimmings), a difference $(P<0.01)$ was detected between averages from each date on all points, showing that claws were softer at the June trimming.

At the May trimming, significant correlations $(P<$ 0.01 ) were found between the hardness at all sole points (Points $1 \mathrm{~b}, 4$, and 5 ), but these points were not correlated with the point in the claw wall (Point 6; Table 4). At the June trimming, Point 6 was correlated only to Point 5 (middle of the sole) $(P=0.016)$. Points $1 \mathrm{~b}$ and 5 showed significant correlations at both dates $(P<$ 0.001 ), whereas Point 4 showed less significant correlations with them. Correlations between the same points on different trimming dates were moderately strong and significant for points $1 \mathrm{~b}(P=0.003), 4(P=0.04)$, and $5(P<0.001)$, but low and nonsignificant for Point $6(P=0.63)$.

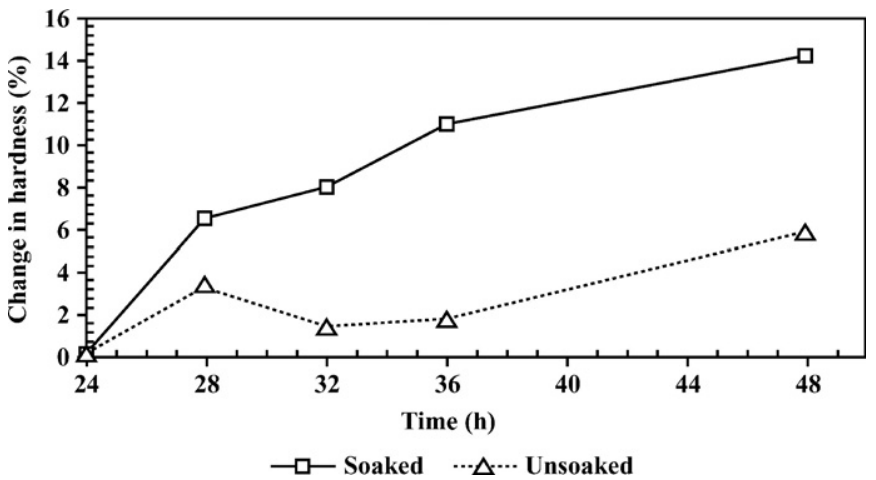

Figure 6. Least square mean values for changes in hardness by treatment from 24 to $48 \mathrm{~h}$ at $5^{\circ} \mathrm{C}$ during the drying period.

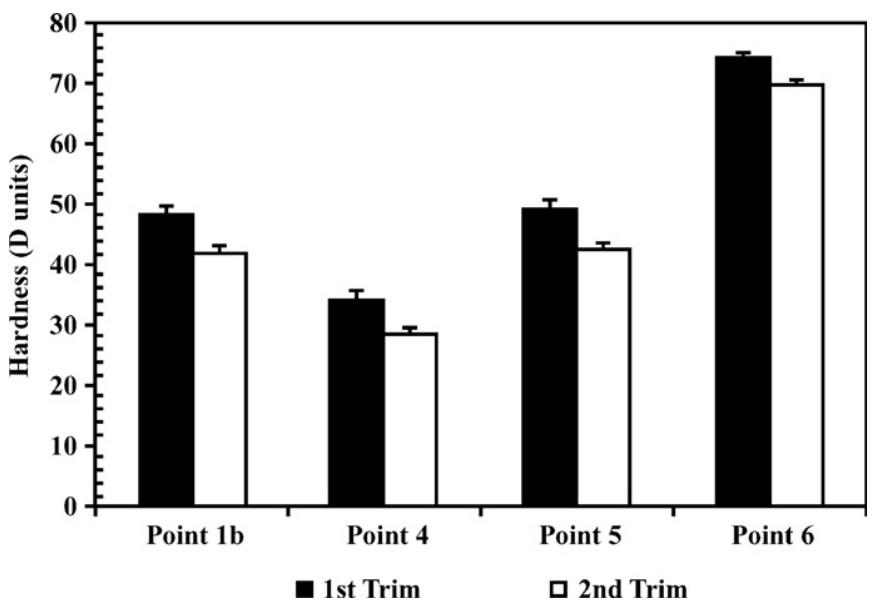

Figure 7. Mean hardness (D units with SEM) of each point on both trimming dates.

Between the 2 claw trimmings, significant reductions in lesion severity scores occurred for $\mathrm{SH}$ and the total sum of scores (all lesions; Figure 8). Remaining claw lesion scores did not differ from one trimming to the next.

At the May trimming, correlations between measures of hardness and lesion severity scores were small, negative, and significant $(P<0.05)$ for severity scores, $\mathrm{SH}$, and average hardness of sole points (Points $1 \mathrm{~b}, 4$, and $5 ; \mathrm{r}=-0.37$ ) No other significant correlations between the hardness and the claw injury scores were detected.

At the June trimming, small, negative, and significant correlations $(P<0.05)$ were found between severity score for WH and hardness at Point $4(\mathrm{r}=-0.43)$, severity scores for ER, average hardness of sole points $(r=$ -0.39 ), and severity scores for UL with hardness of Point 6 (claw wall; $r=-0.36$ ).

Correlation coefficients also were calculated between hardness point averages at the May trimming and the lesion severity score at the June trimming. The correlation $(\mathrm{r}=-0.56)$ was negative $(P<0.01)$ between severity score for ER and the average hardness of the sole points.

Cows were classified as either sound (sum of claw injury score $=0$ ) or injured (sum of claw injury score $>3$ ), and their claw hardness was compared for each date. Differences between the sound and injured cows were found only at the June trimming for average hardness (sound vs. injured: $46.7 \pm 0.8$ vs. $42.0 \pm 0.9 ; P=$ 0.004 ), the average hardness of the sole (sound vs. injured: $37.95 \pm 1.4$ vs. $32.7 \pm 1.00$ respectively; $P=0.007$ ), and the hardness of Point 5 (sound vs. injured: 44.75 \pm 1.48 vs. $36.75 \pm 1.63 ; P=0.005)$.

\section{DISCUSSION}

The first 3 experiments indicate that claws absorb water rapidly. The increase in weight that occurred 
Table 4. Pearson correlations ( $P$ value) between the hardness measures of the 4 points in May (above the diagonal), June (below the diagonal), and between trimmings (on the diagonal).

\begin{tabular}{lllll}
\hline & Point $1 \mathrm{~b}$ & Point 4 & Point 5 & Point 6 \\
\hline Point 1b & $0.47(0.003)$ & $0.45(0.004)$ & $0.76(<0.001)$ & $0.05(0.76)$ \\
Point 4 & $0.49(0.002)$ & $0.34(0.04)$ & $0.55(<0.001)$ & $0.11(0.49)$ \\
Point 5 & $0.62(<0.001)$ & $0.52(<0.001)$ & $0.61(<0.001)$ & $0.24(0.14)$ \\
Point 6 & $0.19(0.26)$ & $-0.08(0.64)$ & $0.39(0.016)$ & $0.08(0.63)$ \\
\hline
\end{tabular}

when the horn of the claw was soaked in water can only be interpreted as water absorption. This weight was lost when the horn was allowed to dry, and this occurred for both the segments of horn and the whole claw. When comparing water absorption as a percentage of the total water absorbed, it is apparent that claws absorb almost $30 \%$ of total water during the 1 st $\mathrm{h}$ and approximately $50 \%$ during the first $4 \mathrm{~h}$. On the other hand, water loss when claws are allowed to dry occurs at a slower rate. By the 4th hour of drying, claws had lost about one-third of total amount of water and approximately $50 \%$ of the total loss by the 8 th hour. Although we could not directly compare Experiments 2 and 3 , the results indicated that temperature (5 vs. $20^{\circ} \mathrm{C}$ ) had little effect on water absorption. As expected, water loss during drying could be temperature dependent. The point of balance (water absorbed = water lost) was reached between 3 and $4 \mathrm{~h}$ of drying at $20^{\circ} \mathrm{C}$, and between 7 and $8 \mathrm{~h}$ of drying at $5^{\circ} \mathrm{C}$. Changes in claw hardness likely followed a similar trend with respect to temperature.

Results also indicated that as claw tissue absorbed water, its hardness decreased proportionally. In the drying period, no significant differences between treatments were found for hardness, but when these values were adjusted to a percentage change in hardness, sig-

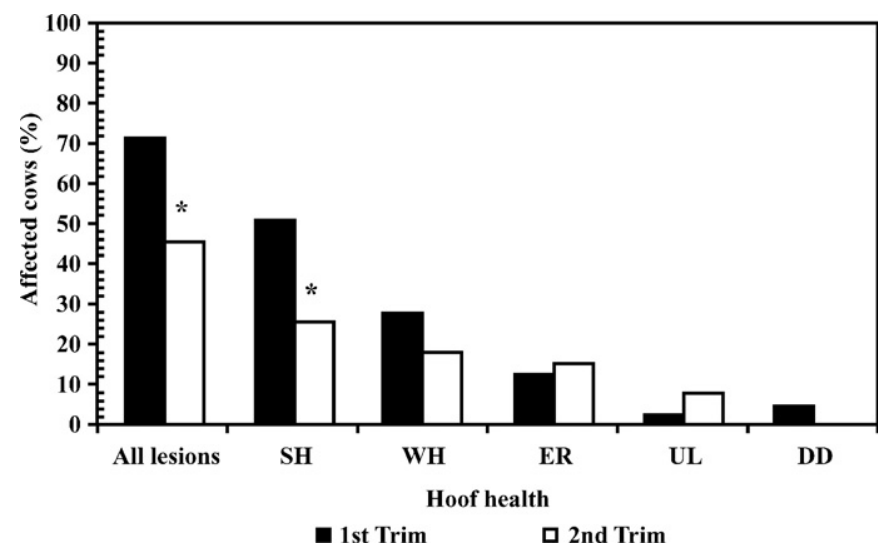

Figure 8. Percentage of affected cows for each type of hoof lesion on both trimming dates. $\mathrm{SH}=$ sole hemorrhage, $\mathrm{WH}=$ white line hemorrhage, $\mathrm{ER}=$ heel erosion, $\mathrm{UL}=$ sole ulcer, and $\mathrm{DD}=$ digital dermatitis. $* P<0.05$. nificant differences were found for treatment, time, and their interaction. These results show that part of the correlation found in previous studies between softness and water content (Vermunt and Greenough, 1995; Higuchi et al., 2003) was caused by claws becoming softer as water was absorbed.

These findings suggest that quite brief exposures to wet or moist surfaces will result in claws absorbing water and consequently becoming softer. Our results confirm that claws will rapidly become moist and softer if proper management measures are not undertaken at the barn. This effect could be critical during midlactation (Higuchi et al., 2003). Eddy and Scott (1980) also suggested that claw horn tissue might be softer during early lactation.

We also found marked differences in hardness between the different regions of the claw, with the wall of the claw being the hardest region and the heel-sole junction the softest. This is determined by the number of horn tubules per unit area, the ratio of medulla and cortex of the horn tubules, and the amount of intertubular horn (Dietz and Prietz, 1981; Kofler et al., 1999). Although horn wall values were measured on the abaxial wall of the claw, mean values found in this experiment (between 77.87 and $79.66 \mathrm{D}$ units) were similar to those of the dorsal wall of the claw (between 75 and 78 D units) reported by Distl et al. (1984). Our results also confirm findings by Manson and Leaver (1988), who reported the toe area of the abaxial wall had a similar degree of hardness as the mid region, and both were greater than all areas of the sole. In our study, the difference between the wall and the sole point averages was around $29 \mathrm{D}$ units, whereas the latter researchers reported a maximum difference of about 15 $\mathrm{D}$ units. This difference could result from the utilization of another kind of durometer by those researchers (Type A). As reported by Grant et al. (1999), while studying the claw of horses, more total lipids are found in the sole than in the wall. Differences in lipid content could be one factor that contributes to the difference in hardness between wall and sole tissues in cattle as well.

Our findings also showed a difference in hardness for the points sampled in our field trial with live cows. In agreement with our findings using pieces of claw, the sole points were softer than the point measured in the 
abaxial wall of the claw. Significant and high correlations were detected between hardness of the different sole points, but results indicate no correlation between sole hardness and the abaxial wall hardness. Therefore, it was concluded that any study attempting to characterize claw hardness must include measures from both the sole and the wall of the claw. Based on our results, we suggest that Points $1 \mathrm{~b}$ or 5 can represent the hardness of the sole, and Point 6 can represent the hardness of the wall. Point 4 can be left out because it is more variable and because its correlations with Points $1 \mathrm{~b}$ and 5 were of lesser magnitude.

When hardness points were grouped according to their location in the claw, all the interactions of treatment and time were significant for hardness during the soaking period. The interaction means that only at certain time points did softening because of wetness affect all regions of the claw, including those considered as harder ones, such as the horn wall. The base of the horn wall (Points 1, 2, and 3) had the largest and earliest changes in hardness, whereas the sole region (Points 4 and 5) seemed to soften steadily during the entire observation period. The wall region (Points 6 and 8) had the least dramatic changes, but it softened as well. These differences in water absorption found at the distinct regions of the claw can be explained by various factors. Mülling et al. (1999) affirmed that fatty acids metabolism, biotin (by its role on lipid metabolism), or both are required for synthesis of an intercellular cementing substance that connects horn cells and regulates permeability characteristics of the horn. The number of microtubules in the horn is another factor that allows water to enter the keratinized tissue. Dietz and Prietz (1981) reported that the sole region has a lower density of microtubules than the wall of the claw, and water is taken up by the intertubular material.

Some studies have described the relationship between water content, hardness, and claw injuries. Bergsten and Pettersson (1992) reported a negative correlation between DM content of the claw and heel-horn erosion. Winckler and Willen (2001) found an inverse relationship between the strength required to puncture the sole horn tissue and the score of hemorrhages. Higuchi et al. (2003) showed a relationship between water content, hardness, and claw health. We found some negative correlations between various hardness measurements and health scores. When comparing hardness averages between cows grouped by health score extremes, sound cows had harder claws than did injured cows. The latter was also true for average hardness points of the sole and for hardness of the midpoint of the sole (Point 5). These results indicate a relationship between hardness and health scores, but it is difficult to determine whether softening of the claw was a cause for, or a consequence of, claw injuries. However, cows with softer soles at the May trimming tended to have more horn ER at the June trimming. The relationship between claw hardness and the occurrence of claw lesions is not simple. Although claw hardness decreased between the May and June claw trimmings, no deterioration in claw health occurred.

\section{CONCLUSION}

Pieces of claw horn and whole digits from claws of dairy cows absorb water rapidly when soaked in water, and much of the water is absorbed during the 1 st $\mathrm{h}$ of soaking. As water is absorbed, the claws become progressively softer. In comparison with water absorption rate, water loss tends to be slower when the claws are allowed to dry. Regions of the claws differ in hardness: walls of the claw are the hardest, whereas the sole is softest. However, all parts of the claw absorb water and become softer. We found some evidence that cows with softer claws tend to have more severe claw lesions, although changes in claw hardness do not inevitably lead to more claw lesions. To reduce the chance of claw injuries, dairy cows should be kept in conditions that allow their claws to stay dry as much as possible.

\section{ACKNOWLEDGMENTS}

Funding was obtained from the Dairy Farmers of Canada and AAFC MII funds. We are grateful to Peter Phillips, Dan Weary, and Heiko Georg for useful discussions. We thank Sophie Neveux, Isabelle Blanchet, Marjolaine St.-Louis, Nadia Champagne and the staff of the Dairy Centre for their help. We also thank Steve Méthot for statistical advisory.

\section{REFERENCES}

Arkins, S., J. Hannan, and J. Sherington. 1986. Effects of formalin footbathing on foot disease and claw quality in dairy cows. Vet. Rec. 118:580-583.

Bergsten, C., and B. Pettersson. 1992. The cleanliness of cows tied in stalls and the health of their claws as influenced by the use of electric trainers. Prev. Vet. Med. 13:229-238.

Blowey, R. W., P. Ossent, C. L. Watson, V. Hedges, L. E. Green, and A. J. Packington. 2000. Possible distinction between sole ulcers and heel ulcers as a cause of bovine lameness. Vet. Rec. 147:110-112.

Dietz, O., and G. Prietz. 1981. Klauenhornquälitat-Klauenhornstatus. Monatsschr Veterinarmed. 36:419-422.

Distl, O., M. Huber, F. Graf, and H. Kräuslich. 1984. Claw measurements of young bulls at performance testing stations in Bavaria. Livest. Prod. Sci. 11:587-598.

Eddy, R. G., and C. P. Scott. 1980. Some observations on the incidence of lameness in dairy cattle in Somerset. Vet. Rec. 106:140-144.

Esslemont, R. J., and M. A. Kossaibati. 1997. Culling in 50 dairy herds in England. Vet. Rec. 140:36-39.

Georg, H., and W. Meyer. 2002. Influence of an improved floor design on the claw health of dairy cows. ASAE Meeting paper No. 024023, 2002 ASAE Annual Meeting, Chicago, IL. 
Grant, E., J. R. Scaife, and M. Birnie. 1999. Characterization and comparison of the lipids of the epidermis of the equine claw wall and sole. Page 219 in Proc. Br. Soc. Anim. Sci. Scarborough, UK, Br. Soc. Anim. Sci., Penicuik, Scotland.

Greenough, P. R., and A. D. Weaver. 1997. Lameness in Cattle. 3rd ed. W. B. Saunders, Philadelphia, PA.

Higuchi, H., T. Maeda, K. Kawai, A. Kuwano, M. Kasamatsu, and H. Nagahata. 2003. Physiological changes in the concentrations of biotin in the serum and milk and in the physical properties of the claw horn in Holstein cows. Vet. Res. Comm. 27:407-413.

Higuchi, H., and H. Nagahata. 2001. Relationship between serum biotin concentration and moisture content of the sole horn in cows with clinical laminitis or sound claws. Vet. Rec. 148:209-210.

Huang, Y. C., R. D. Shanks, and G. C. McCoy. 1995. Evaluation of fixed factors affecting claw health. Livest. Prod. Sci. 44:115-124.

Kofler, J., P. Kübber, and W. Henninger. 1999. Ultrasonographic imaging and thickness measurement of the sole horn and the underlying soft tissue layer in bovine claws. Vet. J. 157:322-331.

Leopold, G., and G. Prietz. 1980. Die Bedeutung der Beziehungen zwischen physikalischen Eigenschaften und histologischen Merkmalen für die Erkennung der Klauenhornqualität beim Rind. Monatsschr Veterinarmed. 35:173-175.

Littell, R. C., P. R. Henry, and C. B. Ammerman. 1998. Statistical analysis of repeated measures data using SAS procedures. J. Anim. Sci. 76:1216-1231.

MacCallum, A. J., C. H. Knight, K. A. K. Hendry, C. J. Wilde, D. N. Logue, and J. E. Offer. 2002. Effects of time of year and reproductive state on the proliferation and keratinisation of bovine claw cells. Vet. Rec. 151:285-289.
Maclean, C. W. 1971. The long-term effects of laminitis in dairy cows. Vet. Rec. 89:34-37.

Manson, F. J., and J. D. Leaver. 1988. The influence of dietary protein intake and of claw trimming on lameness in dairy cattle. Anim. Prod. 47:191-199.

Martig, J., W. P. Leuenberger, and M. Dozzi. 1980. Quality and alterations of bovine claws as a function of different variables. Pages 40-50 in Proc. IIIrd. Int. Symp. Dis. Rum. Dig. Vienna, Austria, Veterinärmedizinische Universität, Vienna, Austria.

Mülling, C. K., H. H. Bragulla, S. Reese, K. D. Budras, and W. Steinberg. 1999. How structures in bovine claw epidermis are influenced by nutritional factors. Anat. Histol. Embryol. 28:103-108.

Vermunt, J. J., and P. R. Greenough. 1995. Structural characteristics of the bovine claw: Horn growth and wear, horn hardness and claw conformation. Br. Vet. J. 151:157-180.

Wells, S. J., A. M. Trent, W. E. Marsh, N. B. Williamson, and R. A. Robinson. 1995. Some risk factors associated with clinical lameness in dairy herds in Minnesota and Wisconsin. Vet. Rec. 136:537-540.

Whitaker, D. A., J. M. Kelly, and E. J. Smith. 1983. Incidence of lameness in dairy cows. Vet. Rec. 113:60-62.

Williams, L. A., G. J. Rowlands, and A. M. Russell. 1986. Effect of wet weather on lameness in dairy cattle. Vet. Rec. 118:259-261.

Winckler, C., and S. Willen. 2001. The reliability and repeatability of a lameness scoring system for use as an indicator of welfare in dairy cattle. Acta Agric. Scand. (Sect. A Anim. Sci. Suppl.) 30:103-107. 